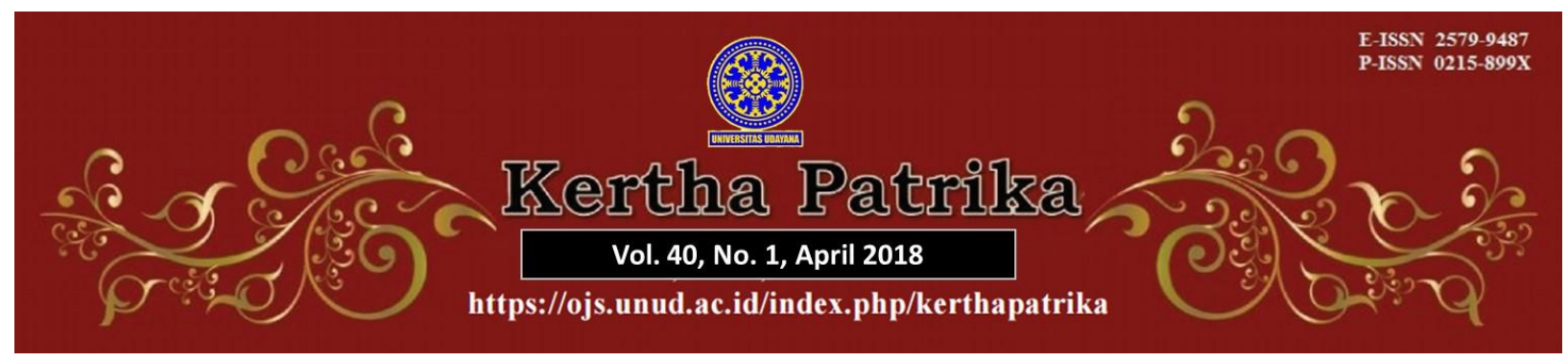

\title{
PEMBAGIAN HARTA WARIS KEPADA ANAK KANDUNG NON MUSLIM MELALUI WASIAT WAJIBAH
}

\author{
Oleh: \\ Eka Apriyudi ${ }^{1}$
}

Program Magister Kenotariatan Universitas Udayana

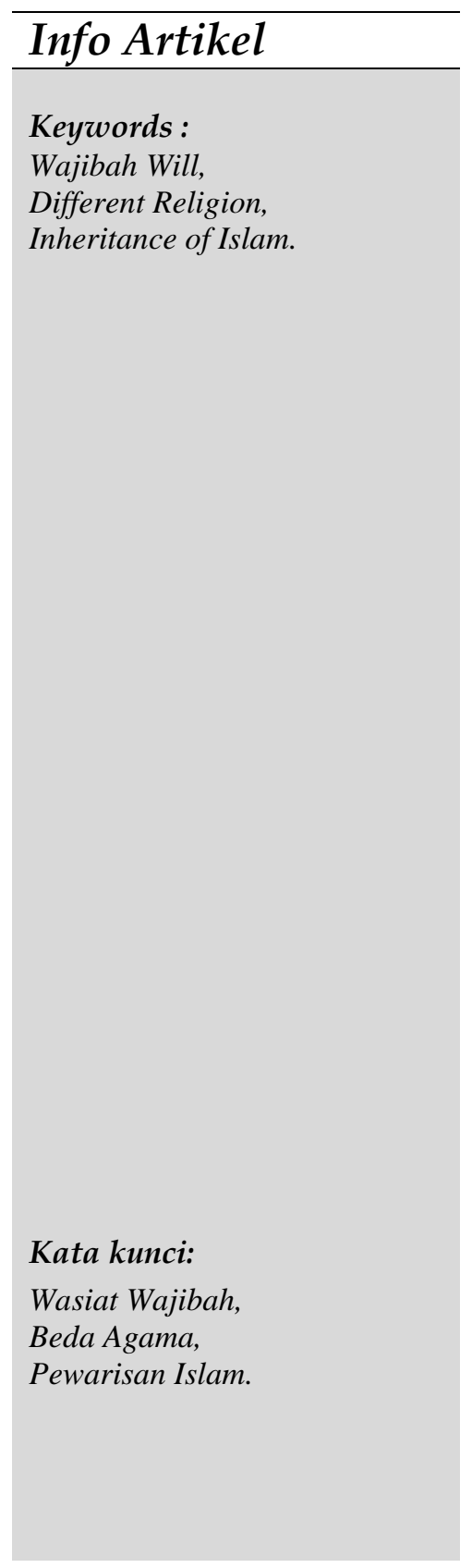

\begin{abstract}
\begin{tabular}{l} 
Abstract \\
\hline The current phenomenon of granting of 'wajibah' testament
\end{tabular} enables non-muslim children to inherit from their father that aims to provide a sense of justice for a child who was left dead by his/her father who is a muslim. Nevertheless in the Qur'an or Hadith does not justify the non-muslim children inherit property from their muslim father. This article is aimed at investigating (1) How the position of non-muslim children with regards to the inheritance that sourced from muslim inheritors?; and (2) How is the distribution of inheritance to the biological non-muslim child through a wajibah testament? The type of this research is normative legal research that uses statute, conceptual, and case approaches. The legal materials are obtained from study of literature to be subsequently analysed by a juridical analysis. The result of this research indicates that (1) The position of nonmuslim children with regards to the inheritance of from muslim inheritors are not as heirs because Islamic Inheritance Law does not recognize the heir to people of different religions (nonmuslim). This is the reason that the position of non-muslim children's rights over the legacy of muslim heir is regulated by the Islamic Law of Inheritance that applicable in Indonesia which puts non-muslim children of the inheritors were not getting inherited but may be granted wajibah testament; and (2) The distribution of inheritance to a non-muslim child through a wajibah testament essentially determines that non-muslim children are entitled to be granted the properties of the heirs who are muslims based on the wajibah testament, that equally amounts to that of the daughters as heirs.
\end{abstract}

\begin{tabular}{l}
\hline Abstrak \\
\hline Pemberian wasiat wajibah memungkinkan ahli waris yang \\
non muslim dengan tujuan untuk memberikan rasa \\
keadilan bagi anak-anak yang ditinggal mati oleh ayahnya \\
yang beragama Islam. Mekipun demikian dalam Al-Qur'an \\
maupun hadis tidak membenarkan anak yang non muslim \\
mewarisi harta dari ayahnya yang beragama muslim. \\
Tulisan ini disusun untuk menganalisis (1) Bagaimana
\end{tabular}

${ }^{1}$ Eka Apriyudi adalah mahasiswa Program magister Kenotariatan Universitas Udayana. Korespondensi dengan penulis melalui email: barberclub09@gmail.com. 


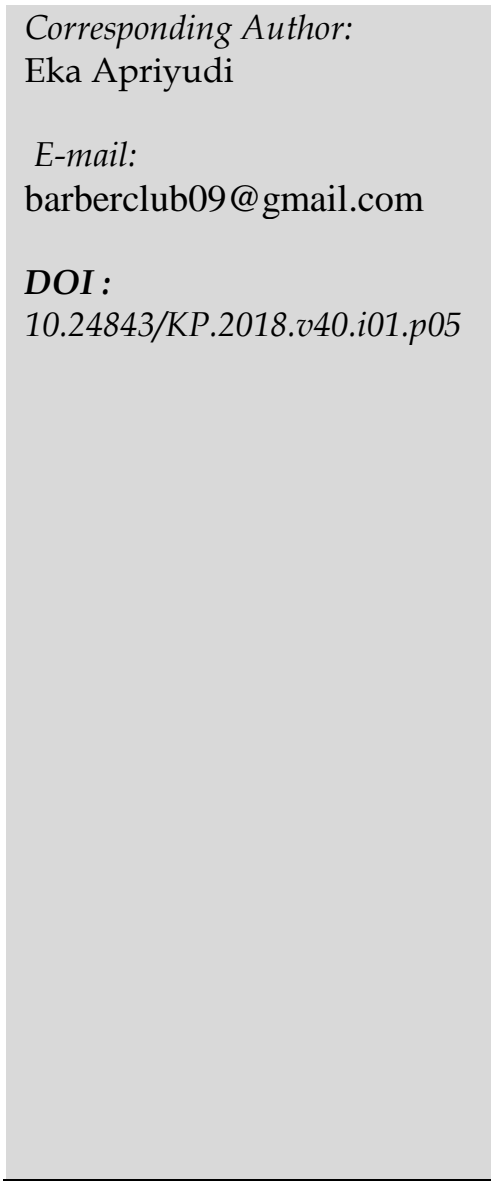

Corresponding Author:

Eka Apriyud

E-mail:

DOI :

10.24843/KP.2018.v40.i01.p05

\section{Pendahuluan}

Hukum kewarisan dalam Islam mendapat perhatian yang besar karena pembagian warisan sering menimbulkan akibat-akibat yang tidak menguntungkan bagi keluarga yang ditinggal mati. ${ }^{2}$ Warisan adalah soal apa dan bagaimana berbagai hak-hak dan kewajiban-kewajiban tentang kekayaan seseorang pada waktu ia meniggal akan beralih kepada keluarga yang masih hidup. Dasar pokok dari semuanya adalah hukum kewarisan Islam yang telah ditetapkan dalam Al-Qur'an dan As-Sunnah kemudian yang diterapkan di dalam masyarakat seperti peraturan Kompilasi Hukum Islam (selanjutnya disebut KHI). ${ }^{3}$

Menurut hukum positif tentang kewarisan Islam yang diatur dalam KHI, untuk dapat mewarisi, antara ahli waris dan pewaris harus beragama Islam, memiliki hubungan darah atau hubungan perkawinan dan tidak terhalang karena hukum untuk menjadi ahli waris (Pasal 171 huruf b dan c KHI), sedangkan dalam hal terjadi perbedaan agama antara pewaris dan ahli waris tidak diatur secara jelas.

2 Sofyan Adhi Styawan. (2016). Tinjauan Yuridis Terhadap Pembagian Harta Waris Kepada Ahli Waris Yang Beda Agama Melalui Wasiat Wajibah. Skripsi. Fakultas Hukum Universitas Muhammadiyah. Surakarta, h. 2.

${ }^{3}$ Ahmad Azhar Bazhar. (2010). Hukum Waris Islam. Universitas Islam Indonesia. Yogyakarta, h. 8 . 
Dalam Al Quran juga tidak ditemukan satu ayat pun yang secara jelas dan tegas melarang waris beda agama. Dasar hukum yang secara jelas dan tegas melarang waris beda agama justru ditemukan dalam hadis riwayat Bukhari, bahwa Nabi Saw bersabda:"Orang muslim tidak mewarisi dari orang kafir, dan orang kafir tidak mewarisi dari orang muslim". ${ }^{4}$ Hadis tersebut juga diriwayatkan oleh Muslim, Tirmizi, Abu Dawud, Ibn Majah, Ahmad, Malik, dan Ad-Darimi. Menurut Riadi, dari segi sanad (rangkaian periwayat) hadis tersebut merupakan hadis sahih, akan tetapi dari segi matan (isi) hadis tersebut diragukan kesahihannya, karena Mu'adz bin Jabal pernah memutus kasus, dalam mana harta warisan dari pewaris Yahudi diberikan kepada ahli waris muslim. ${ }^{5}$ Terhadap hadis yang melarang waris beda agama tersebut, beberapa sahabat seperti Mu'adz, Mu'awiyah, Hasan, Ibn Hanafiyah, Muhammad bin Ali bin Husain, dan Masruq berpendapat bahwa orang muslim dapat mewarisi dari orang nonmuslim, tetapi tidak sebaliknya. Pendapat tersebut berdasarkan hadis: "Islam itu tinggi dan tidak dilampaui" ${ }^{6}$

Dalam hukum waris Islam penghalang mewarisi yang berarti tindakan atau hal-hal yang dapat menggugurkan hak seseorang untuk mewarisi beserta adanya sebab-sebab dan syarat-syarat mewarisi. ${ }^{7}$ Penghalang-penghalang kewarisan tersebut meliputi: pertama, perbudakan, para ulama klasik sepakat bahwa budah tidak berhak waris karena dianggap tidak cakap mengurusi harta miliknya. Segala sesuatu yang dimilik budak secara langsung menjadi milik tuannya, hal didasarkan pada nash Qur'an dalam Qs. An-Nahl (16): 75.8 Kedua, pembunuhan, para fuqaha klasik sepakat bahwa pembunuhan menjadi penghalang mewarisi bagi si pembunuh terhadap harta peninggalan orang yang telah dibunuhnya. Hal ini didasarkan pada sabda Nabi yang mengatakan: "Tidak sesutupun bagi pembunuh hak dari warisan".${ }^{9}$ Ketiga, perbedaan agama, ketentuan penghalan ketiga ini didasarkan pada hadist Nabi yang mengatakan: "Tidak mewarisi seorang muslim terhadap orang kafir, dan tidak mewarisi orang kafir terhadap seorang muslim". ${ }^{10}$

Ulama klasik mengatakan bahwa jika seseorang masuk Islam sebelum dibagikan warisan, maka ia tidak mendapatkan warisan. Riwayat lain yang berasal dari $\mathrm{Mu}^{\prime} \mathrm{az}$ dikatakan: seorang muslim menerima warisan dari orang kafir, tetapi tidak sebaliknya. Hal ini didasarkan pada satu argumen bahwasanya ia pernah mendengar Rasulullah bersabda: "Al-Islaamu Yazidu Wa Laa Yankus". ${ }^{11}$ Diceritakan juga, bahwa ada seorang Yahudi yang mati dan meninggalkan dua orang anak yang satu muslim dan lainnya Yahudi. Kepada yang muslim Mu'az telah membagikan warisan padanya. ${ }^{12}$ Dalam

${ }^{4}$ Shahih Bukhari, Kitab Faraidh, Hadis No. 6267

${ }^{5}$ E. Riadi. (2011). Dinamika Putusan Mahkamah Agung Republik Indonesia dalam Bidang Perdata Islam. Gramata Publishing. Jakarta, h. 284.

${ }^{6}$ W. Az-Zuhaili. (1985). Kitab al-Figh 'ala Mazahib Al-Arba'ah. Dar Al-Fikr. Damaskus, h. 263.

7 Sofyan Adhi Styawan, Op.cit, h. 3.

${ }^{8}$ Fathur Rahman. (1981). Ilmu Waris. Cet. Ke-2. Al-Ma'arif. Bandung, h. 122.

${ }^{9}$ Al-Imam al-Bukhori, Matn al-Bukhori, IV: 165, hadist riwayat an-Nasa'I dan ad-Daruqutni dari Amir bin Syu'aib.

${ }^{10} \mathrm{Ibid}$., hadist riwayat al-Bukhori dari Usamah bin Zaid.

11 Al-Imam Ahmad bin Hanbal. (tanpa tahun). Al-Musnad Ahmad. Darul Hadist. Beirut, hadist riwayat Ahmad dari $\mathrm{Mu}^{\prime} \mathrm{az}$.

${ }^{12}$ M. Ali as-Sabuni. (tanpa tahun). Pembagian Warisan Menurut Islam. penerjemah A.M Basamalah. Gema Insani Press. Jakarta, h. 43. 
riwayat lain dikatakan: "Laa Yatawaarasu Ahlu Millataini Syattaa", dalam konteks ini Jumhur ulama klasik sepakat bahwa yang dimaksud "millataini" ialah yang satu agama Islam dan yang lainnya bukan. ${ }^{13}$

Timbulnya permasalahan hak kewarisan anak yang beragama non-muslim dari suami muslim seperti yang diuraikan di atas, karena KHI tidak mengatur anak kandung yang beragama non-muslim, yang secara hukum Islam tidak berhak menerima warisan dari ayahnya yang beragama Islam, apakah dapat diberikan wasiat wajibah. Pasal $209 \mathrm{KHI}$ hanya mengatur pemberian wasiat wajibah kepada orangtua angkat dan anak angkat sebagaimana ketentuan Pasal 209 KHI sebagai berikut :

(1) Harta peninggalan anak angkat dibagi berdasarkan Pasal 176 sampai dengan Pasal 193 tersebut di atas, sedangkan terhadap orang tua angkat yang tidak menerima wasiat diberi wasiat wajibah sebanyak-banyaknya $1 / 3$ dari harta wasiat anak angkatnya.

(2) Terhadap anak angkat yang tidak menerima wasiat diberi wasiat wajibah sebanyak-banyaknya $1 / 3$ dari harta warisan orang tua angkatnya.

Ketentuan pada Pasal 209 KHI tersebut di atas menunjukkan bahwa orangtua angkat dan anak angkat yang seharusnya tidak berhak atas warisan dapat diberikan wasiat wajibah mengingat orangtua angkat dan anak angkat merupakan orang-orang dekat dari ahli waris. Ketentuan pada Pasal 209 KHI tidak mengatur (norma kosong) apakah anak kandung yang beragama non-muslim yang tadinya tidak berhak atas warisan ayahnya dapat diberikan wasiat wajibah sebagaimana halnya orangtua angkat dan anak angkat, mengingat anak kandung juga merupakan orang dekat bahkan orang terdekat dengan pewaris.

Berangkat dari adanya norma kosong dalam Pasal 209 KHI yang tidak mengatur apakah anak kandung yang beragama non-muslim yang tadinya tidak berhak atas warisan suaminya dapat diberikan wasiat wajibah sebagaimana halnya orangtua angkat dan anak angkat, maka peneliti tertarik untuk melakukan penelitian dalam bentuk tesis dengan judul "Pembagian Harta Waris Kepada Anak Kandung Non Muslim Melalui Wasiat Wajibah". Berdasarkan latar belakang masalah yang telah diuraikan di atas, maka rumusan masalah dalam penelitian ini dapat dikemukakan dalam research questions adalah (1) Bagaimana kedudukan anak non muslim terhadap harta warisan pewaris beragama Islam? dan (2) Bagaimana pembagian harta waris kepada anak kandung non muslim melalui wasiat wajibah?

Adapun tujuan dari penelitian ini adalah (1) Untuk memahami dan menganalisis kedudukan anak non muslim terhadap harta warisan pewaris beragama Islam; (2) Untuk memahami dan menganalisis pembagian harta waris kepada anak kandung non muslim melalui wasiat wajibah.

\section{Metode Penelitian}

Berangkat dari adanya norma kosong dalam Pasal 209 KHI yang tidak mengatur apakah anak kandung yang beragama non-muslim yang tadinya tidak berhak atas warisan suaminya dapat diberikan wasiat wajibah sebagaimana halnya orangtua

13 Ahmad Ibn Ali Hajar al-Asqalani. (tanpa tahun). Fatbul Bari. al-Maktabah as-Salafiah. Ttp, h. 50-51. 
angkat dan anak angkat, maka dalam penelitian ini digunakan jenis penelitian hukum normatif. Penelitian hukum normatif (normative legal research) merupakan penelitian yang dilakukan dengan cara mengkaji peraturan perundang-undangan yang berlaku atau diterapkan terhadap suatu permasalahan hukum tertentu. Penelitian hukum normatif seringkali disebut dengan penelitian doktrinal, yaitu penelitian yang objek kajiannya adalah dokumen peraturan perundang-undangan dan bahan pustaka. ${ }^{14}$ Penelitian hukum normatif juga disebut penelitian yang difokuskan untuk mengkaji penerapan kaidah-kaidah atau norma dalam hukum positif. ${ }^{15}$ Dalam peneltian normatif hukum dipandang identik dengan norma-norma tertulis, yang dibuat dan diundangkan oleh lembaga atau pejabat yang berwenang dan meninjau hukum sebagai suatu sistem normatif yang otonom, mandiri, tertutup dan terlepas dari kehidupan masyarakat nyata. ${ }^{16}$

Penulis terinspirasi dari sejumlah karya ilmiah yang mengangkat topik sejenis. Salah satunya adalah karya yang disusun Sofyan Adhi Styawan yang berjudul "Tinjauan Yuridis terhadap Pembagian Harta Waris Kepada Ahli Waris yang Beda Agama Melalui Wasiat Wajibah", 17 yang menjadi rujukan bagi tulisan ini. Selain itu, terdapat pula tulisan Kadi Sukarna dan Jevri Kurniawan Hambali yang berjudul "Implementasi Hak atas Ahli Waris Anak Kandung Non Muslim dalam Perspektif Hukum Islam yang Berlaku di Indonesia."18.

\section{Pembahasan}

\subsection{Tinjauan Tentang Wasiat Dan Wasiat Wajibah Dalam Hukum Kewarisan Islam}

\subsubsection{Wasiat}

Wasiat ialah suatu hasrat atau keinginan seseorang yang diungkapkan secara lisan atau tetulis oleh seseorang tentang harta bendanya yang dilakukan menjelang kematiannya. Secara bahasa jika di perhatikan dari segi asal kata, wasiat itu berasal dari bahasa Arab, wāsaitu syāusyihi berarti aușaltuhu (saya menyambungkannya). orang yang berwasiat adalah orang yang menyambungkan, yang telah ditetapkan pada waktu hidupnya sampai dengan sesudah wafatnya. Adapun menurut istilah syar'i, wasiat ialah seseorang memberi barang atau piutang, atau sesuatu yang bermanfaat, dengan catatan pemberian tersebut akan menjadi hak milik si penerima wasiat setelah meninggalnya si pemberi wasiat. ${ }^{19}$

Sedangkan secara istilah, wasiat adalah suatu tindakan hukum yang dilakukan oleh seseorang untuk mengalihkan sebagian harta kekayaannya kepada orang lain atau kepada suatu badan hukum yang pelaksanaannya baru berlaku setelah pewasiat

14 Peter Mahmud Marzuki. (2011). Penelitian Hukum. Kencana Prenida Media. Jakarta, h. 34.

15 Johny Ibrahim. (2012). Teori dan Metodologi Penelitian Hukum Normatif. Banyumedia. Malang, h. 295.

16 Ronny Hanitijo Soemitro. (2008) Metode Penelitian Hukum dan Jurimetri. Alumni. Jakarta, h. 13-14.

17 Sofyan Adhi Styawan. Op.cit., h. 47.

18 Kadi Sukarna dan Jevri Kurniawan Hambali. (2017). Implementasi Hak atas Ahli Waris Anak Kandung Non Muslim dalam Perspektif Hukum Islam yang Berlaku di Indonesia. Jurnal Ius Constituendum. 2 (2), h. 7.

19 Mustofa Hasan. (2011). Pengantar Hukum Keluarga. CV. Pustaka Setia. Bandung, h. 354-355. 
meninggal dunia. ${ }^{20}$ Sayid Sabiq dalam bukunya Fiqh al-sunnah juga mengemukakan pengertian wasiat secara istilah yaitu pemberian seseorang kepada orang lain, berupa benda, utang atau manfaat, agar si penerima memiliki pemberian itu setelah si pewasiat meninggal. ${ }^{21}$

Suatu pendapat mengemukakan bahwa wasiat adalah pemilikan yang disandarkan pada sesudah meninggalnya pewasiat dengan jalan tabarru' (kebaikan tanpa menuntut imbalan). Pengertian ini untuk membedakan antara wasiat dan hibah. Jika hibah berlaku sejak pemberi menyerahkan pemberiannya, dan diterima oleh yang menerimanya, maka wasiat berlaku setelah si pemberi meninggal dunia. Hal ini sejalan dengan definisi Fuqaha' Hanafiyah: "Wasiat adalah tindakan seseorang memberikan hak kepada orang lain untuk memiliki sesuatu baik berupa benda atau manfaat secara sukarela (tabarru') yang pelaksanaanya ditangguhkan setelah peristiwa kematian orang yang memberi wasiat.22 Fuqaha' Malikiyah, Syafi'iyah, dan Hanabilah memberi definisi yang lebih rinci, yaitu "suatu transaksi yang mengharuskan penerima wasiat berhak memiliki 1/3 harta si pewasiat kepada penerima". ${ }^{23}$

Adapun pengertian wasiat yang terdapat dalam KHI di Indonesia adalah pemberian suatu benda dari pewaris kepada orang lain atau lembaga yang akan berlaku setelah pewaris meninggal dunia (pasal 171 huruf f). Ketentuan wasiat ini ini terdapat dalam pasal 194-209 yang mengatur secara keseluruhan prosedur tentang wasiat. ${ }^{24}$

Dalam hukum perdata positif, wasiat sering disebut dengan istilah testament. Namun demikian, ada perbedaan-perbedaan prinsipil antara wasiat menurut hukum Islam dan testament dalam KUH perdata, terutama yang menyangkut kriteria dan persyaratannya. Kompilasi mengambil jalan tengah, yaitu meskipun wasiat merupakan transaksi tabarru', agar pelaksanaanya mempunyai kekuatan hukum, perlu ditata sedemikian rupa, agar diperoleh ketertiban dan kepastian hukum. ${ }^{25}$ Wasiat tampak memilki kedudukan yang sangat penting dalam masyarakat, lebih-lebih dalam masyarakat muslim. ${ }^{26}$

\subsubsection{Wasiat Wajibah}

Menurut Ahmad Rafiq, wasiat wajibah adalah tindakan yang dilakukan penguasa atau hakim sebagai aparat Negara untuk memaksa atau member putusan wasiat bagi orang yang telah meninggal dunia, yang diberikan kepada orang tertentu dalam keadaan tertentu pula. Dalam versi lain Chairuman Pasaribu dan Suhrawardi K.Lubis

20 Moh. Muhibbib, Abdul Wahid. (2009). Hukum Kewarisan Islam Sebagai Pembaharuan Hukum Positif di Indonesia. Sinar Grafika. Jakarta, h. 186-187.

21 Sayid Sabiq. (tanpa tahun). Figh al-Sunnah, juz 3, Maktabah Dar al-Taurats, Kairo, hal.414. Hal senada juga terdapat dalam buku Ahmad Rofiq, Hukum Perdata Islam di Indonesia, PT. Raja Grafindo Persada, Jakarta, hal.353.

22 Abd al-Rahim. (tanpa tahun). al-Muhadlarat fi al-Mirats al-Muqaran. tanpa penerbit. Kairo, h. 117.

23 Sayid Sabiq, Op.cit., h. 415.

24 Abdul Manan. (2008). Aneka Masalah Hukum Perdata di Indonesia. Kencana. Jakarta, h. 150.

25 Ibid., h. 354.

26 Muhammad Amin Summa. (2005). Hukum Keluarga Islam di Dunia Islam. PT. Raja Grafindo Persada. Jakarta, h. 128. 
mengemukakan bahwa wasiat wajibah adalah wasiat yang dipandang sebagai telah dilakukan oleh seseorang yang akan meninggal dunia, walaupun sebenarnya ia tidak meninggalkan wasiat itu. ${ }^{27}$

Dasar hukum penentuan wasiat wajibah adalah kompromi dari pendapat-pendapat ulama salaf dan kalaf. Fatchur Rahman mengemukakan wasiat wajibah ini muncul karena:

1. Hilangnya unsur ikhtiar bagi orang yang member wasiat dan munculnya kewajiban melalui perundang-undangan atau surat keputusan tanpa tergantung kerelaan orang yang berwasiat dan persetujuan orang yang menerima wasiat.

2. Ada kemiripan dengan ketentuan pembagian harta pusaka dalam penerimaan laki-laki dua kali lipat bagian perempuan.

3. Orang yang berhak menerima wasiat wajibah adalah cucu laki-laki maupun perempuan, baik pancar laki-laki maupun perempuan yang orang tuanya mati yang mendahului atau bersama-sama dengan kakek atau neneknya.

KHI di Indonesia mempunyai ketentuan tersendiri tentang konsep wasiat wajibah ini, yaitu membatasi orang yang berhak menerima wasiat wajibah ini yakni kepada anak angkat dan orang tua angkat saja. Dalam Pasal 209 KHI, disebutkan bahwa:

(1) Harta peninggalan anak angkat dibagi berdasarkan Pasal 176 sampai dengan Pasal 193 tersebut di atas, sedangkan terhadap orang tua angkat yang tidak menerima wasiat diberi wasiat wajibah sebanyak-banyaknya $1 / 3$ dari harta wasiat anak angkatnya.

(2) Terhadap anak angkat yang tidak menerima wasiat diberi wasiat wajibah sebanyak-banyaknya 1/3 dari harta warisan orang tua angkatnya.

Secara garis besar antara waris pengganti (penggantian kedudukan) dengan wasiat wajibah adalah sama. Perbedaanya jika dalam wasiat wajibah dibatasi penerimaannya yaitu sebanyak-banyaknya sepertiga dari harta warisan, maka dalam waris pengganti adalah menggantikan hak yang disesuaikan dengan hak yang diterima orang yang digantikan itu.

Untuk mengetahui besarnya wasiat wajibah dan berapa besarnya ahli waris lainnya, menurut professor Hasbi Ash shiddieqy hendaklah diikuti langkah-langkah sebagai berikut: 28

1. Dianggap bahwa orang yang meninggal dunia lebih dulu daripada pewaris masih hidup. Kemudian warisan dibagikan kepada para ahli waris yang ada, termasuk ahli waris yang sesungguhnya telah meninggal lebih dulu itu. Bagian orang yang disebutkan terakhir inilah menjadi wasiat wajibah, asal tidak lebih dari sepertiga.

2. Diambil bagian wasiat wajibah dari warisan yang ada. Mungkin, besarnya sama dengan bagian yang seharusnya diterima oleh orang yang meninggal dunia lebih dahulu daripada pewaris, mungkinan pula sepertiga.

3. Sesudah warisan diambil wasiat wajibah, sisa warisan inilah yang dibagikan kepada ahli waris lain.

27 Abdul Manan. Op.cit., h. 166.

28 A. Rachmad Budiono. (1999). Pembaruan Hukum Kewarisan Islam di Indonesia. PT. Citra Aditya Bakti. Bandung, h. 28. 
Oleh karena wasiat wajibah ini mempunyai titik singgung secara langsung dengan hukum kewarisan islam, maka pelaksanaannya diserahkan kepada kebijaksanaan hakim untuk menetapkannya dalam proses pemeriksaan perkara waris yang diajukan kepadanya. Hal ini penting diketahui oleh hakim karena wasiat wajibah itu mempunyai tujuan untuk mendistribusikan keadilan, yaitu memberikan bagian kepada ahli waris yang mempunyai pertalian darah namun nash tidak memberikan bagian yang semestinya, atau orang tua angkat dan anak angkat yang mungkin sudah banyak berjasa kepada si pewaris tetapi tidak diberi bagian dalam ketentuan hukum waris Islam, maka hal ini dapat dicapai jalan keluar dengan menerapkan wasiat wajibah sehingga mereka dapat menerima bagian dari harta pewaris. ${ }^{29}$

\subsection{Kedudukan Anak Non Muslim Terhadap Harta Warisan Pewaris Beragama Islam}

\subsubsection{Hak Non Muslim terhadap Hak Waris}

Dalam pembahasan hukum kewarisan sebelumnya telah disebutkan bahwa salah satu penghalang dari hak-hak kewarisan ialah adanya perbedaan agama antara muwarris dengan ahli warisnva, seperti agama muwaris beragama non Islam sedangkan ahli waris beragama Islam, atau sebaliknya. Posisi perbedaan agama keduanya menjadi penghalang serius dan keberadaan hak-hak waris, sebagaimana hadis riwavat Bukhari sebutkan: "Tidak mewariskan seorang muslim terhadap orang kafir, dan tidak mewariskan orang kafir terhadap orang muslim". Demikian juga hadis yang mengatakan: "Laa Yatawaa rasu Ahlu Millataini Syattaa".

Dalam konteks hukum hak waris kafir (non muslim) para ulama' klasik dan kontemporer berbeda-beda pendapat. Para ulama' imamiyah berpendapat bahwa seorang muslim berhak mewarisi non muslim. Kalau salah seorang diantara anak-anak pewaris ada yang non muslim kemudian masuk Islam sesudah orang yang diwarisi itu meninggal dan harta peninggalannya sudah dibagikan kepada pemilikinya maka menurut kesepakatan para ulama' madzhab, orang tersebut tidak berhak atas waris.

Dalam konteks penghalang kewarisan karena perbedaan agama juga termasuk yang dalam ajaran Islam dikatagorikan sebagai orang murtad. Murtad secara umum didehnisikan oleh para ulama' klasik sebagai keluarnya seseorang yang semula memeluk agama Islam kemudian mengingkarinya. ${ }^{30}$ Keluarnya seseorang baik karena berpindah agama ataupun tidak memeluk agama yang secara umum oleh ajaran Islam orang tersebut dianggap telah ingkar (kufr). Terkait dengan kewarisan, status orang murtad disamakan dengan orang kafir yang berarti mempunyai kedudukan yang sama dengan orang kafir asli. Karena orang murtad tidak dapat menjadi muwaris bagi ahli warisnya yang muslim ataupun sebaliknya. Dasar hukum dalam hal ini ialah mengambil pada rujukan keumuman hadis yang diriwayatkan oleh Usamah bin Zaid. 31

29 Abdul Manan. Op.cit., h. 169.

30 Abdul Kadir Audah. (tanpa tahun). At-Tasyri Al-Jina'I Al-Islam, 1:534, Muhammad Abu Zahra, Al-Jarimab Wa Al-Uqubab Fi Al-Alfiqb Al-Islam, Darul Fikr. Bairut, h. 188.

31 Al-Jaziri. (1996). Kitab Al-Fighi Ala Mazhab Al-Arba'ah. Dar Al-Kutub. Bairut, h. 436-437. 
Pendapat ulama klasik yang secara umum mengatakan bahwa perbedaan agama menjadi penghalang pewarisan ditentang oleh beberapa pemikir kontemporer. Abdullah Ahmad An-Na'im mengatakan bahwa salah satu diskriminasi hukum keluarga dan hukum perdata syariah ialah berkaitan dengan perbedaan agama. Perbedaan agama adalah penghalang dari seluruh pewarisan, sehingga seorang muslim tidak akan dapat mewarisi dari maupun wariskan non muslim. ${ }^{32}$ Menurut An$\mathrm{Na}^{\prime}$ im pengabaian berbagai perbedaan tentang pembenaran-pembenaran historis, berbagai masalah diskriminasi terhadap perempuan dan non muslim di bawah syariah tidak lagi dapat dibenarkan.

Senada dengan pendapat An-Na'im ialah Asgar Ali Engineer. Menurut Asgar, sebuah masyarakat Islami (jami'I at-tauhid) tidak akan mengakui adanya diskriminasi dalam bentuk apapun, apakah berdasar ras, suku, agama, dan kelas. ${ }^{33}$ Menurut Asgar, tauhid tidak sebatas monoteisme murni tetapi meluas mencakup dimensi sosiologis. Harus diingat, kesatuan manusia tidak boleh direduksi hanya untuk kesatuan antar iman saja. Karena pada dasarnya kesatuan manusia yang sesungguhnya melintasi garisgaris keyakinan. ${ }^{34}$

Terkait dengan hak waris non muslim, KHI lebih merujuk pada pendapat para ulama klasik yang menegaskan bahwa perbedaan agama antara muwaris dengan ahli waris menjadi penghalang terjadinya proses kewarisan. Hal ini bisa dibaca dalam Pasal 171 point b KHI menyatakan "Pewaris adalah orang yang pada saat meninggalnya atau yang dinyatakan meninggal berdasarkan putusan pengadilan beragama Islam, meninggalkan ahli waris dan harta peninggalan".

Dalam Pasal yang sama 171 poin c KHI menyatakan "Ahli waris adalah orang yang pada saat meninggal dunia mempunyai hubungan darah atau hubungan perkawinan dengan pewaris, beragama Islam dan tidak terhalang karena hukum untuk menjadi ahli waris". Ketentuan keberagamaan seseorang dapat ditentukan lewat identitasnya, hal ini jelas dalam Pasal 172 yang berbunyi "Ahli waris yang dipandang beragama Islam apabila diketahui dari Kartu Identitas atau pengakuan atau amalan atau kesaksian, sedangkan bayi yang baru lahir atau anak yang belum dewasa, beragama menurut ayahnya atau lingkungannya".

Ketentuan dalam KHI sangat tegas bahwa hak kewarisan otomatis terputus ketika berkaitan dengan perbedaan agama. Aturan dalam KHI mendasarkan seutuhnya pada pendapat ulama klasik khususnya Imam Syafi'i. Bahkan dalam Surat Edaran Biro Peradilan Agama tanggal 18 Pebruari 1958 Nomor B/I/735 hukum materiil yang

32 Abdullah Ahmed An-Na'im. (1990). Dekonstruksi Syari'ah: Wacana Kebebasan Sipil, HAM dan Hubungan Internasional dalam Islam. LkiS. Yogyakarta, h. 337.

33 Asgar Ali Engineer. (1993). Islam dan Pembebasan. LKiS dan Pustaka Pelajar. Yogyakarta, h. 94.

34 M. Agus Nuryanto. (2001). Islam, Teologi Pembebasan dan Kesetaraan Gender, Studi Atas Pemikiran Asgar Ali Engineer. UII Press. Yogyakarta, h. 42. 
dijadikan pedoman dalam bidang-bidang hukum KHI adalah bersumber pada 13 (tiga belas) buah kitab yang kesemuanya merupakan madzhab Syafi'i. ${ }^{35}$

\subsubsection{Kedudukan Anak Non Muslim terhadap Harta Warisan Pewaris Beragama Islam}

Syariat Islam menetapkan aturan waris dengan bentuk yang sangat teratur dan adil. Di dalamnya ditetapkan hak kepemilikan harta bagi setiap manusia, baik laki-laki maupun perempuan dengan cara yang legal. Syariat Islam juga menetapkan hak pemindahan kepemilikan seseorang sesudah meninggal dunia kepada ahli warisnya, dari seluruh kerabat dan nasabnya, tanpa membedakan antara laki-laki dan perempuan, besar atau kecil. Al-Qur'an menjelaskan dan merinci secara detail hukumhukum yang berkaitan dengan hak kewarisan tanpa mengabaikan hak seorang pun. Bagian yang harus diterima semuanya dijelaskan sesuai kedudukan nasab terhadap pewaris, apakah dia sebagai anak, ayah, istri, suami, kakek, ibu, paman, cucu, atau bahkan hanya sebatas saudara seayah atau seibu. ${ }^{36}$

Oleh karena itu, Al-Qur'an merupakan acuan utama hukum dan penentuan pembagian waris, sedangkan ketetapan tentang kewarisan yang diambil dari hadits Rasulullah SAW. dan ijma' para ulama sangat sedikit. Dapat dikatakan bahwa dalam hukum dan syariat Islam sedikit sekali ayat Al-Qur'an yang merinci suatu hukum secara detail dan rinci, kecuali hukum waris ini. Hal demikian disebabkan kewarisan merupakan salah satu bentuk kepemilikan yang legal dan dibenarkan AlIah SWT. Di samping bahwa harta merupakan tonggak penegak kehidupan baik bagi individu maupun kelompok masyarakat. ${ }^{37}$

Istilah ahli waris ini berarti orang yang berhak menerima pusaka (peninggalan) orang yang telah meninggal. Sedangkan warisan berarti harta peninggalan, pusaka, dan surat wasiat. Pewaris adalah orang yang memberi pusaka, yakni orang yang meninggal dunia dan meninggalkan sejumlah harta kekayaan, pusaka, maupun surat wasiat. ${ }^{38}$ Untuk dapat berlangsungnya proses pewarisan ada tiga unsur yang sangat esensial yang harus dipenuhi yaitu pewaris, harta warisan dan ahli waris. ${ }^{39}$ Mencermati hal itu dimana dari unsur pewaris sudah mengalami perkembangan karena pewaris selain ayah, ibu juga sebagai pewaris. Dalam unsur pewaris telah mencerminkan kesetaraan gender. Di samping pewaris, untuk dapat terjadinya proses pewarisan unsur harta warisan merupakan hal yang sangat penting, karena harta warisan sering kali menjadi penyebab terjadi keretakan hubungan dalam keluarga. Harta warisan adalah harta yang yang ditinggalkan oleh pewaris. ${ }^{40}$

35 Soesilo dan Pramudji (Penerjemah). (tanpa tahun). Kitab Undang-Undang Hukum Perdata (Burgelijk Wetboek). Rhedbook Publisher. h. 552.

36 Sofyan Adhi Styawan. Op.cit., h. 4-5.

37 Ibid., h. 5.

38 Ibid.

39 Ni Nyoman Sukerti, Ida Bagus Putra Atmadja, I G.A. Mas Rwa Jayantiari, I G. A. Tirta Sari Dewi dan G. A. Bagus Agastya Pradnyana. (2016). Pewarisan Pada Masyarakat Adat Bali Terkait Ahli Waris Yang Beralih Agama. Acta Comitas. 2(2), h. 132.

40 Ni Nyoman Sukerti, I Gusti Ayu Agung Ariani. (2014). Perkembangan Kedudukan Perempuan dalam Hukum Adat Waris Bali. Acta Comitas. 3(7), h. 249-250. 
Mayoritas ulama mengajukan alasan, apabila yang menjadi ketentuan hak mewarisi adalah saat pembagian warisan, tentu akan muncul perbedaan pendapat tentang mengawalkan atau mengakhirkan pembagian warisan. ${ }^{41}$ Mengenai orang murtad orang yang keluar dari agama Islam, para ulama memandang mereka mempunyai kedudukan hukum tersendiri. Hal ini karena orang murtad dipandang telah memutuskan tali (shilah) syari'ah dan melakukan kejahatan agama. Karena itu, meskipun dalam isyarat Al-Qur'an bahwa mereka dikatagorikan sebagai orang kafir, para ulama menyatakan bahwa harta warisan orang murtad tidak diwarisi oleh siapa pun, termasuk ahli warisnya yang sama-sama murtad. Harta peninggalannya dimasukkan ke baitul-mal sebagai harta fai' atau rampasan, dan digunakan untuk kepentingan umum. ${ }^{42}$

KHI telah mengatur secara jelas siapa saja yang dikelompokkan menjadi ahli waris. Hal tersebut terdapat dalam Kompilasi Hukum Islam Pasal 174 ayat (1). Mengenai pembahasan ini penulis ingin mengkaji mengenai kedudukan anak sebagai ahli waris non-muslim menurut KHI. Di dalam KHI mengenai kedudukan ahli waris telah diatur secara jelas dalam Pasal 174 ayat (1) KHI menyebutkan bahwa yang berhak menjadi ahli waris tersebut ada dua kriteria yaitu adanya hubungan darah yang meliputi anak laki-laki, perempuan, kakek, paman sedangkan menurut dari hubungan perkawinan yaitu duda atau janda, hal tersebut dikuatkan dengan ketentuan Pasal 171 huruf $\mathrm{c}$ KHI. 43

Selanjutnya, dalam KHI yang tersirat dalam pasal diatas bahwa ahli waris tidak hanya yang memiliki hubungan darah ataupun perkawinan melainkan juga harus beragama muslim. Dapat dikatakan seseorang itu berkedudukan sebagai ahli waris ia harus memenuhi syarat yang ada pada Pasal 171 huruf c KHI yang memiliki hubungan darah atau perkawinan serta harus beragama Islam. Lalu bagaimana jika seorang anak yang beragama Kristen (non-muslim) apakah kedudukannya sama seperti ahli waris non muslim. ${ }^{44}$

Wasiat wajibah hanya diperuntukkan untuk anak angkat serta orangtua angkat dan bersarnya wasiat wajibah $1 / 3$ dari harta orang tua angkatnya. Tetapi hakim pada umumnya menggunakan penafsiran bahwa kedudukan ahli waris non-muslim itu bisa diganti dengan penetapan wasiat wajibah. Padahal aturan yang ada pada KHI serta hadist itu sudah mengatur secara jelas bahkan tidak ada pengecualian untuk ahli waris non-muslim. ${ }^{45}$

Peneliti merujuk pada kesimpulan yang diambil oleh Sofyan Adhi Styawan, sebagai berikut: 46

41 Fathur Rahman, Op.cit., h. 12.

42 Muslich Maruzi. (1981). Pokok-pokok Ilmu Waris. Pustaka Amani. Semarang, hal.16 dan Sofyan

Adhi Styawan, Op.cit., h.5-6.

${ }^{43}$ Sofyan Adhi Styawan, Op.cit., h.6.

44 Ibid.

${ }^{45}$ Ibid, h.7. Sofyan Adhi Styawan, Op.cit., h.6.

${ }^{46} \mathrm{Ibid}, \mathrm{h} .7$. 
"bahwa apa yang sudah ada dan sudah diatur dalam KHI serta hadist di atas itu tidak dapat ditafsirkan dengan sendirinya karena seorang yang memiliki hubungan darah sekalipun atau memiliki hubungan perkawinan jika orang tersebut beragama non-muslim kedudukannya tidak dapat menjadi ahli waris dari Muslim. Jadi ketika hakim memberikan ijtihad menyamakan kedudukannya yang diganti dengan penetapan wasiat wajibah tentu tidak dapat dibenarkan, karena dalam Pasal 209 KHI tentang wasiat wajibah juga tidak mengatur bahwa anak angkat kedudukannya sama dengan anak yang memiliki hubungan darah langsung dengan pewaris."

Pendapat Sofyan di atas juga dikuatkan dengan pendapat para ulama yang menegaskan bahwa orang murtad merupakan penggugur hak mewarisi, yakni orang yang telah keluar dari Islam. Berdasarkan ijtihad para ulama, murtad termasuk dalam kategori perbedaan agama sehingga orang murtad tidak dapat mewarisi orang Islam. Bahkan hadist yang diriwayatkan oleh Imam Bukhari dan Imam Muslim, tidak ada penafsiran lain bahwa orang muslim tidak mewariskan harta kepada orang kafir, demikian juga orang kafir, karena murtad artinya menjadi kafir, maka ketentuan tersebut sama, artinya tidak ada dalil lain yang membenarkan orang murtad mewariskan harta kepada orang muslim, karena murtad itu sendiri adalah menjadi kafir. 47

Sofyan mengutip jawaban dari Allah atas permohonan Nabi Nuh sebagai berikut:48

"Ya Tuhanku, sesungguhnya anakku adalah keluargaku, dan sesungguhnya janji Engkau adalah benar, dan Engkau adalah hakim seadil-adilnya. Kemudian Allah berfirman: "Hai Nuh, sesungguhnya dia bukanlah termasuk keluargamu yang dijanjikan akan diselamatkan. Sesungguhnya perbuatannya adalah perbuatan yang tidak baik. Sebab itu janganlah kamu memohon kepadaku sesuatu yang tidak mengetahui hakekatnya. Sesungguhnya aku memperingatkan kepadamu supaya kamu jangan termasuk orang-orang yang tidak berpengetahuan". ${ }^{9}$ Berdasarkan kutipan dari pembicaraan Allah SWT dengan Nabi Nuh A.S disimpulkan bahwa sebenarnya Allah SWT lah yang Maha mengetahui atas segala apa yang tidak diketahui manusia, sehingga walaupun seseorang tersebut memiliki hubungan darah, apabila tidak beriman kepada Allah SWT, maka Allah SWT tidak meridhai orang beriman tersebut untuk mendoakan atau memberikan harta serta pertolongannya kepada orang yang tidak beriman."

Hal tersebut semakin mempertegas bahwa Hukum waris Islam tidak mengenal adanya proses pewarisan kepada orang yang berbeda agama (non-muslim). Menjadi jelas pula bahwa konsep maqashid al-syariah (tujuan diturunkannya syariat Islam) menggariskan bahwa tujuan pewarisan Islam secara operasional adalah untuk memelihara harta dan keturunan. Hal ini berarti bahwa kedudukan anak non muslim tidak dapat disamakan dengan anak yang beragama Islam. Dengan demikian, anak non muslim tidak dapat mendapatkan harta warisan dari pewaris karena bertentangan dengan tujuan syariat yang ingin memelihara agama, memelihara jiwa, bahkan memelihara akal. Pada

${ }^{47}$ Zakiah Daradjat, 1995, Ilmu Figh Jilid 3, Dana Bhakti Wakaf, Yogyakarta, h. 27-31.

${ }^{48}$ Sofyan Adhi Styawan. Op.cit., h. 8.

${ }^{49}$ Ibid. 
prinsipnya, harta itu merupakan titipan dari Allah SWT yang harus dipelihara untuk digunakan demi kemaslahatan menusia yang beriman kepada Allah SWT.50

\subsection{Pembagian Harta Waris Kepada Anak Kandung Non Muslim Melalui Wasiat Wajibah}

\subsubsection{Hukum Islam tidak Mengatur Pemberian Harta Warisan pada Anak yang Beragama Non Muslim}

Al Qur'an sebagai pedoman hidup umat Islam tidak secara tegas mengatur adanya hukum mewaris antara umat Islam dengan umat yang berbeda keyakinan dengan agama Islam. Namun berdasarkan hadist Rasulullah S.AW. yang berbunyi "Disampaikan dari Abu 'Asyim, dari Ibn Juraji, dar Ibn Syihan, dari Ali bin Husain, dari 'Amr bin Usman, dari Usamah bin Zaid r.a. bahwa Rasulullah S.A.W bersabda : tidak ada warisan bagi seorang muslim kepada orang kafir, dan tidak ada warisan pula dari orang kafir kepada orang muslim" ${ }^{51}$ Amin Husein juga berpendapat bahwa hadist dari rasulullah yang tersebut di atas yang menguatkan dan memberikan alasan mengapa tidak ada pewarisan bagi ahli waris yang berbeda agama dengan pewaris muslim termasuk kepada anak kandung yang non muslim. ${ }^{52}$ menyebutkan sejarah nabi Nuh. A.S yang meminta Allah untuk menyelamatkan anaknya, namun permintaan tersebut ditolak oleh Allah. ${ }^{53}$

Berdasarkan sejarah dari cerita nabi maupun hadist Rasulullah S.A.W mencerminkan bahwa dalam hukum waris Islam tidak mengenal adanya pewarisan kepada orang yang berbeda keyakinan. Meskipun dalam Al-Qur'an tidak ditegaskan secara jelas bahwa perbuatan itu dilarang. Tujuan kewarisan sendiri menuut konsep maqashid alsyariah secara operasional adlah untuk memelihara harta dan keturunan. ${ }^{4}$ Menurut Habiburrahman pemberian harta warisan kepada ahli waris yang berbeda agama bukan hanya bertentangan dengan syariat Islam namun juga bertentangan dengan tujuan dari syariat sendiri yang ini memelihara jiwa, memelihara akal, dan bahkan memelihara agama. ${ }^{55} \mathrm{Hal}$ inilah yang menjadi alasan bahwanya Islam tidak memperbolehkan adanya pewarisan kepada ahli waris yang berbeda agama. Pandangan tentang harta tersebut adalah titipan Tuhan sehingga harus dipelihara seperti yang diajarkan oleh Tuhan dan digunakan demi kemaslahatan manusia yang beriman kepada Tuhan (Allah). Rasulullah S.A.W sendiri juga bersabda bahwa harta warisan tersebut tidak boleh merugikan ahli waris yang berhak atas harta warisan tersebut. Hal ini sebagai mana sabda Rasulullah yang berbunyi " tidak boleh mendatangkan kemudharatan bagi ahli waris. Haram mewakafkan hanya yang dapat menimbulkan kerugian bagi ahli waris, sebagaiman hadist Rasulullah S.A.W: tidak memudharatkan dan tidak dimudaratkan". ${ }^{56}$ Makna dari hadist tersebut adalah bahwa apabila disatukan dengan hadist rasulullah serta kisah dari nabi Nuh adalah pemberian harta kepada orang yang bukan muslim merupakan suatu yang mudharat

50 Ibid., h. 9.

51 Habiburrahman. (2011). Rekonstruksi Hukum Kewarisan Islam di Indonesia. Kencana. Jakarta, h. 78 .

52 Amin Husein Nasution. (2012). Hukum Kewarisan suatu Analisis Komparatif Pemikiran Mujtahid dan Kompilasi Hukum Islam. Rajawali Pers., Jakarta, h. 81.

53 Lihat jawaban dari Allah atas permohonan Nabi Nuh dapat dilihat pada 3.2.2.

54 Habiburrahman. Op.cit., h. 234.

55 Ibid., h. 235.

56 Ibid., h. 76. 
atau tidak ada manfaatnya. Hal ini didasari bahwa tujuan dari syarat Islam sendiri yang ingin memelihara agamanya. Salah satu konsultan hukum perbendapat bahwa memang benar tidak ada penyebutan hukum waris diberikan kepada orang yang berbeda agama, maka dari itu alangkah baiknya bila sebuah keluarga yang berbeda agama sebelum salah satu keluarga meninggal, calon pewaris tersebut membuat suatu hibah untuk diberikan kepada ahli waris yang berbeda agama. Jikalau pewaris tidak meninggalkan hibah atau wasiat, apabila dengan kerelaan dari ahli waris yang menerima wasiat, ahli waris yang terhalang diberikan haknya.

\subsubsection{Perkembangan Kontemporer}

Baik Al-Qur'an maupun Hadits tidak menjelaskan tentang bagian ahli waris untuk non-muslim termasuk anak yang non muslim. Maraknya kasus pewarisan beda agama merupakan salah satu faktor penyebab munculnya sikap tidak setuju dari ahli waris (non-muslim) terhadap pembagian harta yang dinilai tidak adil. Merespon perkembangan ini, Pengadilan Agama bahkan Mahkamah Agung mengeluarkan putusan-putusan baru yang relatif mencerminkan sikap afirmasi terhadap fenomena yang terjadi ini, kendatipun dinilai tidak sesuai dengan hukum Islam tentang kewarisan beda agama. ${ }^{57}$

Pada umumnya majelis hakim dalam memberikan pertimbangan dan mengabulkan gugatan penggugat dengan alasan keadilan dan kemanusiaan, kendatipun sudah melenceng dari aturan hukum Islam Mahkamah Agung nampaknya mengacu kepada pertimbangan legalitas dan moral dan menggunakan kajian sosiologis yang mempertimbangkan aspek psikologis dan norma yang hidup secara figh,. Pertimbangan hakim untuk memberikan wasiat wajibah kepada ahli waris non muslim termasuk anak kandung non muslim menjadi semacam 'jalan ke luar' yang bersifat kompromistis yang di dalam hukum Islam dikenal dengan istilah Ijbari, yakni maksud peralihan harta tersebut terjadi dengan sendirinya menurut ketentuan Allah tanpa tergantung kepada kehendak pewaris atau permintaan ahli warisnya.

\section{Kesimpulan}

1. Kedudukan anak non muslim terhadap harta warisan pewaris beragama Islam adalah bukan sebagai ahli waris. Hukum Waris Islam pada prinsipnya tidak mengakui anak yang non muslim untuk dapat mewaris dari ayahnya yang merupakan seorang muslim. Hukum Islam menentukan bahwa pewarisan bertujuan untuk memelihara harta dan keturunan sebagaimana merujuk pada konsep maqashid al-syariah (tujuan diturunkannya syariat Islam). Hal inilah yang kemudian memunculkan praktik pemberian wasiat wajibah bagi anak non muslim di Indonesia yang menungkinkan mereka untuk mendapatkan warisan dari harta milik ayahnya yang merupakan seorang muslim.

2. Pembagian harta waris kepada anak kandung non muslim melalui wasiat wajibah pada intinya menentukan bahwa ahli waris yang beragama bukan Islam tetap bisa mendapat harta dari pewaris yang beragama Islam berdasarkan wasiat wajibah yang bagiannya sama dengan bagian anak perempuan sebagai ahli waris.

\footnotetext{
${ }^{57}$ Sofyan Adhi Styawan. Op.cit., h. 9.
} 


\section{Saran}

1. Kepada pemerintah disarankan agar dapat membuat aturan atau menyempurnakan aturan yang sudah ada secara lebih jelas dan terperinci khususnya dalam mengatur Hukum Wasiat Wajibah sesuai dengan yang telah disyariatkan oleh Islam sehingga hukum berwasiat kepada anak kandung yang non muslim memiliki legalitas hukum.

2. Kepada stakeholder atau pemangku kepentingan disarankan agar Pasal 209 ayat (2) KHI ditafsirkan secara luas bahwa wasiat wajibah bukan hanya untuk orang tua angkat dan anak angkat saja, melainkan juga diterapkan terhadap anak kandung yang berbeda agama.

\section{Daftar Pustaka}

\section{Buku}

Abd al-Rahim. (tanpa tahun). al-Muhadlarat fi al-Mirats al-Muqaran. tanpa penerbit. Kairo.

Abdul Kadir Audah. (tanpa tahun). At-Tasyri Al-Jina'I Al-Islam, 1:534, Muhammad Abu Zahra, Al-Jarimab Wa Al-Uqubab Fi Al-Alfiqb Al-Islam, Darul Fikr. Bairut, .

Abdullah Ahmed An-Na'im. (1990). Dekonstruksi Syari'ah: Wacana Kebebasan Sipil, HAM dan Hubungan Internasional dalam Islam. LkiS. Yogyakarta.

Ahmad Ibn Ali Hajar al-Asqalani. (tanpa tahun). Fatbul Bari. al-Maktabah asSalafiah. Ttp.

Al-Imam Ahmad bin Hanbal. (tanpa tahun). Al-Musnad Ahmad. Darul Hadist. Beirut, hadist riwayat Ahmad dari $\mathrm{Mu}^{\prime}$ az.

Al-Jaziri. (1996). Kitab Al-Fiqhi Ala Mazhab Al-Arba'ah. Dar Al-Kutub. Bairut.

Asgar Ali Engineer. (1993). Islam dan Pembebasan. LKiS dan Pustaka Pelajar. Yogyakarta.

Bazhar, Ahmad Azhar. (2010). Hukum Waris Islam. Universitas Islam Indonesia. Yogyakarta.

Budiono, A. Rachmad. (1999). Pembaruan Hukum Kewarisan Islam di Indonesia. PT. Citra Aditya Bakti. Bandung.

Fathur Rahman. (1981). Ilmu Waris. Cet. Ke-2. Al-Ma'arif. Bandung.

Habiburrahman. (2011). Rekonstruksi Hukum Kewarisan Islam di Indonesia. Kencana. Jakarta.

Ibrahim, Johny. (2012). Teori dan Metodologi Penelitian Hukum Normatif. Banyumedia. Malang.

M. Ali as-Sabuni. (tanpa tahun). Pembagian Warisan Menurut Islam. penerjemah A.M Basamalah. Gema Insani Press. Jakarta.

Manan, Abdul. (2008). Aneka Masalah Hukum Perdata di Indonesia. Kencana. Jakarta.

Marzuki, Peter Mahmud. (2011). Penelitian Hukum. Kencana Prenida Media. Jakarta. 
Muhammad Amin Summa. (2005). Hukum Keluarga Islam di Dunia Islam. PT. Raja Grafindo Persada. Jakarta.

Muhibbib Moh, Abdul Wahid. (2009). Hukum Kewarisan Islam Sebagai Pembaharuan Hukum Positif di Indonesia. Sinar Grafika. Jakarta.

Muslich Maruzi. (1981). Pokok-pokok Ilmu Waris. Pustaka Amani. Semarang, hal.16 dan Sofyan Adhi Styawan.

Mustofa Hasan. (2011). Pengantar Hukum Keluarga. CV. Pustaka Setia. Bandung.

Nasution, Amin Husein. (2012). Hukum Kewarisan suatu Analisis Komparatif Pemikiran Mujtahid dan Kompilasi Hukum Islam. Rajawali Pers., Jakarta.

Nuryanto, M. Agus. (2001). Islam, Teologi Pembebasan dan Kesetaraan Gender, Studi Atas Pemikiran Asgar Ali Engineer. UII Press. Yogyakarta.

Riadi, E.. (2011). Dinamika Putusan Mahkamah Agung Republik Indonesia dalam Bidang Perdata Islam. Gramata Publishing. Jakarta.

Sayid Sabiq. (tanpa tahun). Figh al-Sunnah, juz 3, Maktabah Dar al-Taurats, Kairo, hal.414. Hal senada juga terdapat dalam buku Ahmad Rofiq, Hukum Perdata Islam di Indonesia, PT. Raja Grafindo Persada, Jakarta.

Soemitro, Ronny Hanitijo. (2008) Metode Penelitian Hukum dan Jurimetri. Alumni. Jakarta.

Soesilo dan Pramudji (Penerjemah). (tanpa tahun). Kitab Undang-Undang Hukum Perdata (Burgelijk Wetboek). Rhedbook Publisher..

W. Az-Zuhaili. (1985). Kitab al-Fiqh 'ala Mazahib Al-Arba'ah. Dar Al-Fikr. Damaskus.

Zakiah Daradjat, 1995, Ilmu Fiqh Jilid 3, Dana Bhakti Wakaf, Yogyakarta.

\section{Skripsi}

Sofyan Adhi Styawan. (2016). Tinjauan Yuridis Terhadap Pembagian Harta Waris Kepada Ahli Waris Yang Beda Agama Melalui Wasiat Wajibah. Skripsi. Fakultas Hukum Universitas Muhammadiyah. Surakarta.

\section{$\underline{\text { Jurnal }}$}

Ni Nyoman Sukerti, Ida Bagus Putra Atmadja, I G.A. Mas Rwa Jayantiari, I G. A. Tirta Sari Dewi dan G. A. Bagus Agastya Pradnyana. (2016). Pewarisan Pada Masyarakat Adat Bali Terkait Ahli Waris Yang Beralih Agama. Acta Comitas. 2(2), h. 132.

Sukarna, Kadi, Jevri Kurniawan Hambali. (2017). Implementasi Hak atas Ahli Waris Anak Kandung Non Muslim dalam Perspektif Hukum Islam yang Berlaku di Indonesia. Jurnal Ius Constituendum. 2 (2), h. 7.

Sukerti, Ni Nyoman, I Gusti Ayu Agung Ariani. (2014). Perkembangan Kedudukan Perempuan dalam Hukum Adat Waris Bali. Acta Comitas. 3(7).

\section{Perundang-Undangan}

Kitab Undang-Undang Hukum Perdata (Burgelijk Wetboek)

Kompilasi Hukum Islam (KIH). 